\title{
Consumer Characteristics and Consumption Analytics of Frequently Consumed Food Categories in Mining Areas
}

Ekpor Anyimah-Ackah (Corresponding Author)

Department of Food Science and Technology, Kwame Nkrumah University of Science and Technology, (KNUST), Kumasi, Ghana, West Africa

Email: aaekpor@yahoo.com

\section{Isaac W. Ofosu}

Department of Food Science and Technology, Kwame Nkrumah University of Science and Technology, (KNUST), Kumasi, Ghana, West Africa

\section{Herman Erick Lutterodt}

Department of Food Science and Technology, Kwame Nkrumah University of Science and Technology, (KNUST), Kumasi, Ghana, West Africa

\section{Godfred Darko}

Department of Chemistry, Kwame Nkrumah University of Science and Technology (KNUST), Kumasi, Ghana, West Africa

\begin{abstract}
The WHO/FAO have requested data on food consumption to better understand the increasing toxicological results of foodstuffs. The aim of this study was to determine the food consumption characteristics of the consumers living in smallscale mining areas. Commonly consumed food crops of each category: fruit, cereals, vegetables, legumes and root tubers were selected. In all, 308 consumers were sampled using a one-week dietary recall tool and a stratified sampling method of the consumers. The @ Risk Microsoft add-in was used to analyze the data. The results show that the adolescents (1017 years) consumed cowpea (233.90 g/day) and cassava (666.96g/day) at a relatively higher level compared to children (3-9 years) and adults (18-64 years). Likewise, adults consumed yam (136.65g/day), maize (1739.37g/day), rice $(1272.40 \mathrm{~g} / \mathrm{day})$, pineapple $(184.97 \mathrm{~g} / \mathrm{day})$ and watermelon $(656.55 \mathrm{~g} / \mathrm{day})$ at a relatively higher level compared to children and adolescents. On the contrary, whereas children generally consumed lower quantities of food, they presented higher exposure frequency to cowpea (364 days/year), root tubers (36-364 days/year) and grains (286-364 days/year) compared to adults and adolescents. Both adolescent and adult population subgroups presented higher exposure frequency to vegetables (364 days/year) relative to children (104-364 days/year). The findings further show that, in increasing order rice and maize are the most consumed crops. The adult population subgroup, in the study area may be vulnerable to contaminants in maize grains than other dishes categories due to the high mass consumed and high exposure duration. Children may be vulnerable to contaminants in maize grains because of the high exposure frequency.

Keywords: Food categories; Food consumption; Mining areas; Variables of exposure.
\end{abstract}

\section{Introduction}

Food availability and consumption trends and projections have been found critical for sustainable food security for all, especially the poor. It is believed that, changes in food consumption patterns significantly affect, adversely, the health outcomes and quality of life [1,2]. In order to monitor the levels of risks, food consumption data is required for exposure assessment of consumers to food-borne hazards [3, 4]. The level of data quality is essential to the robustness of exposure and risk assessment of food-borne hazards. To this end, the European Food and Safety Authority (EFSA) prescribed the estimation of mass of food, exposure frequency and exposure duration in dietary recall studies [5]. Additionally, according to the EFSA Guidance on the EU Menu Methodology, food consumption (g/day) estimates require such anthropometric property as body weight for context $[3,5]$. Further, in the guidance, food details including name, local descriptors and processing methods must accompany food consumption data in order to improve the quality of exposure assessments.

Food consumption data collected at the individual level categorized into population subgroups including 3-9 years, 10-17 years and 18-64 years age categories, enables age-specific analysis of exposure and enhance profiling of vulnerable groups. In regulatory monitoring, food consumption data is usually reported in summary statistics as snapshots of consumption in the population. For example, the Comprehensive Food Consumption Database of EFSA prefers the central tendency measures (example mean and median) along with upper and lower percentiles [3]. However, distribution fitting of the elements of exposure paints a better picture of consumption in that it maximizes data use efficiency [6]. In addition, it serves as a convenient and effective store of the entire data if used properly [7].

The EFSA FoodEx 2 exposure hierarchy food categories defines tiers of classification to aid effective comparison of food consumption data [3, 8]. Level 7 is the highest, most specific and most detailed level. This level 
provides appropriate details for comparative and harmonized but food specific consumption data collection across national boundaries. However, they are not adequate in assessing subnational target areas.

Recent research findings from the study area $[9,10]$ indicate that mining activities release existing hazards from the earth's crust into the environment. Further, these research findings suggest that chemical hazards can bioaccumulate in the food chain. This means exposures and risks of food - borne hazards in mining areas need continuous and thorough monitoring to ensure early detection and prevention of potential toxicities. World bodies including WHO, FAO and EFSA have collected and built food consumption databases [8, 11, 12]. However, since food consumption patterns change, risk assessments require up-to-date data on consumption at the individual level in susceptible and targeted areas of concern. Therefore, the purpose of this study is to provide current essential age disaggregated food consumption data in an area with prevailing informal mining activities as a tool for exposure and risk assessment of food-borne hazards.

\section{Materials and Methods}

\subsection{Study Area} Ghana.

The study area (Figure 1) was purposively restricted to seven sites in four districts in the Western Region of

Figure-1. Map of the Western region showing the study areas.

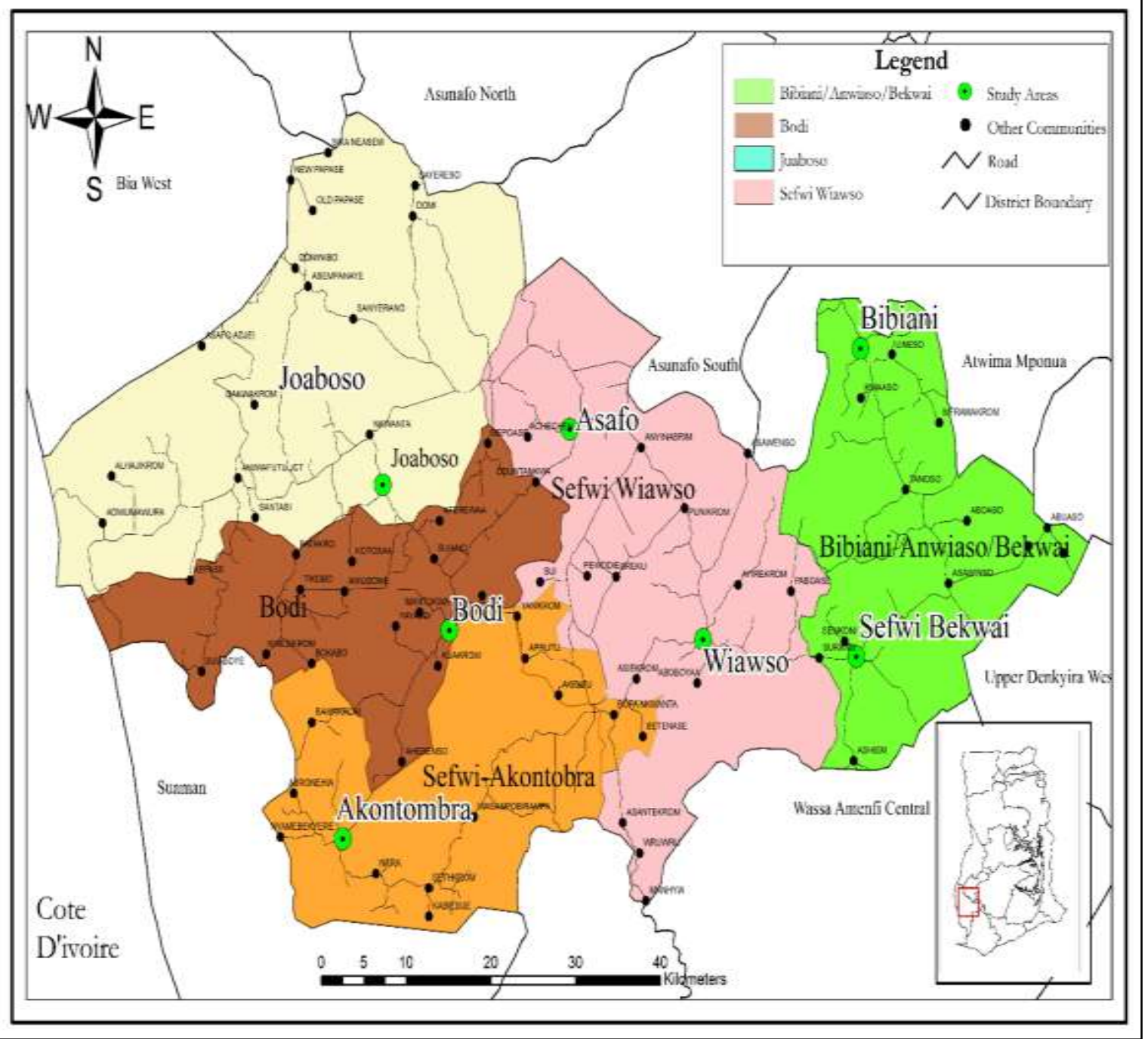

The study area was chosen because there are artisanal or small-scale, unregulated gold mining, locally known as "galamsey", rife in there [13,14]. Western region covers an area of approximately 23,921 square kilometers, forming about $10 \%$ of Ghana's total land area and is rich in gold ore $[15,16]$. The study, which was conducted in June 2017, collected food samples from selected towns: Akontombra (Akontombra district), Bibiani, Bekwai (Bibiani Anhwiaso Bekwai district), Asafo, Sefwi Wiaso (Sefwi-Wiawso district) Bodi and Juaboso (Juaboso district).

\subsection{Study Protocol}

The Committee on Human Research and Publications Ethics (CHPRE) of the Kwame Nkrumah University of Science and Technology (KNUST) and Komfo Anokye Teaching Hospital (KATH) approved the study after a comprehensive review of the research proposal and satisfying all requirements. Three trained field technicians 
assisted with the data and sample collection. Food consumption data was collected using one-week diet recall survey. In addition, the study collected sociodemographic data including age, gender, education, employment and marital status. The foods collected (Table 1) had the main components as yam, cassava (roots and tubers), rice, maize (grains and cereals), pineapple, watermelon (fruits), cabbage, tomatoes (vegetables) and cowpea (legumes).

The study protocol was pre-tested on KNUST campus on 50 students and appropriately amended. Of the 308 respondents, selected using stratified sampling method, $50 \%$ were male and $50 \%$ were female. In addition, the age stratification was such that $50 \%$ were children and $50 \%$ were adults. For each group, the team selected every fifth person approached at each study site for a face-to-face interview.

Table-1. Food dishes sampled and main components

\begin{tabular}{|c|c|c|c|}
\hline English name & Scientific name & Local name & Typical dishes \\
\hline \multicolumn{4}{|l|}{ Cereals } \\
\hline Maize & Zea mays & Abele & Banku, kenkey, porridge \\
\hline Rice & Oryza sativa & Awule & Plain rice, jollof, fried rice, waakye \\
\hline \multicolumn{4}{|c|}{ Roots and tubers } \\
\hline Yam & Dioscorea spp & Elue & Boiled yam, fried yam \\
\hline Cassava & Manihot esculenta & Bede & Fufu, banku, entew \\
\hline \multicolumn{4}{|l|}{ Legumes } \\
\hline Cowpea & Vigna unguiculata & Aluba & Gari and beans, beans stew \\
\hline \multicolumn{4}{|l|}{ Fruits } \\
\hline Watermelon & Citrullus lanatus & & \\
\hline Pineapple & Ananas comosus & & \\
\hline \multicolumn{4}{|l|}{ Vegetables } \\
\hline Tomato & Lycopersicon esculentum & Tomatense & Tomato stew, light soup \\
\hline Cabbage & Brassica oleracea & & Cabbage stew, salad \\
\hline
\end{tabular}

Before the interview, however, the approval of each respondent was sought after going through a consent form with him or her. The purpose, time scale and nature of the study as well as the role of the respondent was explained in Twi or Nzema - the local dialects, to the respondent. Additionally, parental consent was sought for children. In all 308 respondents, 44 each from Akontombra, Asafo, Bekwai, Bibiani, Bodi, Juaboso and Wiawso, were successfully interviewed. The weight of each respondent was taken with a digital balance. To estimate portion sizes, the study randomly sampled four portions of each dish from each study site and weighed them. The $95^{\text {th }}$ percentile value of the weight of each dish was used as its representative portion size.

\subsection{Data Analysis}

According to the US Environmental Protection Agency (US EPA) [6, 17] guide on risk assessment, the exposure elements are hazard concentration (C), mass of food consumed (MF), exposure frequency (EF), exposure duration (ED), body weight (BW) and averaging time (AT). Given these exposure elements, the US EPA defines the exposure to a given food - borne hazard, as the chronic daily intake (CDI) and models it as in Equation 1:

$C D I=(C \times M F \times E F \times E D) /(B W \times A T)$

The raw data was analyzed and descriptive statistics: minimum, maximum, mean, mode, median $5^{\text {th }}$ and $95^{\text {th }}$ percentiles, were obtained using IM SPSS version 24 (IBM Corporation, 2016). Palisade @ Risk version 7 (Palisade Corporation, 2017) was used to fit distribution for the exposure elements: weight of consumers (BW/kg), quantity of food consumed ( $\mathrm{MF} / \mathrm{g}$ per day), exposure frequency (EF/days per year) and exposure duration (ED/years). The Akaike Information Criterion (AIC) was used to select the best-fitted distribution in terms of robustness and minimum data loss. Tukey's multiple comparison test was used to test the differences in the means of consumption for the various food categories.

\section{Results and Discussion}

\subsection{Distribution of Dishes in Study Sites Among Gender and Education Levels of Consumers}

The results (Figure 2) indicate that more people consumed tomato - based dishes in the study area $(100 \%)$ relative to rice dishes (99\%). 
Figure-2. Percentage distribution of dishes by study sites, gender and education of consumers

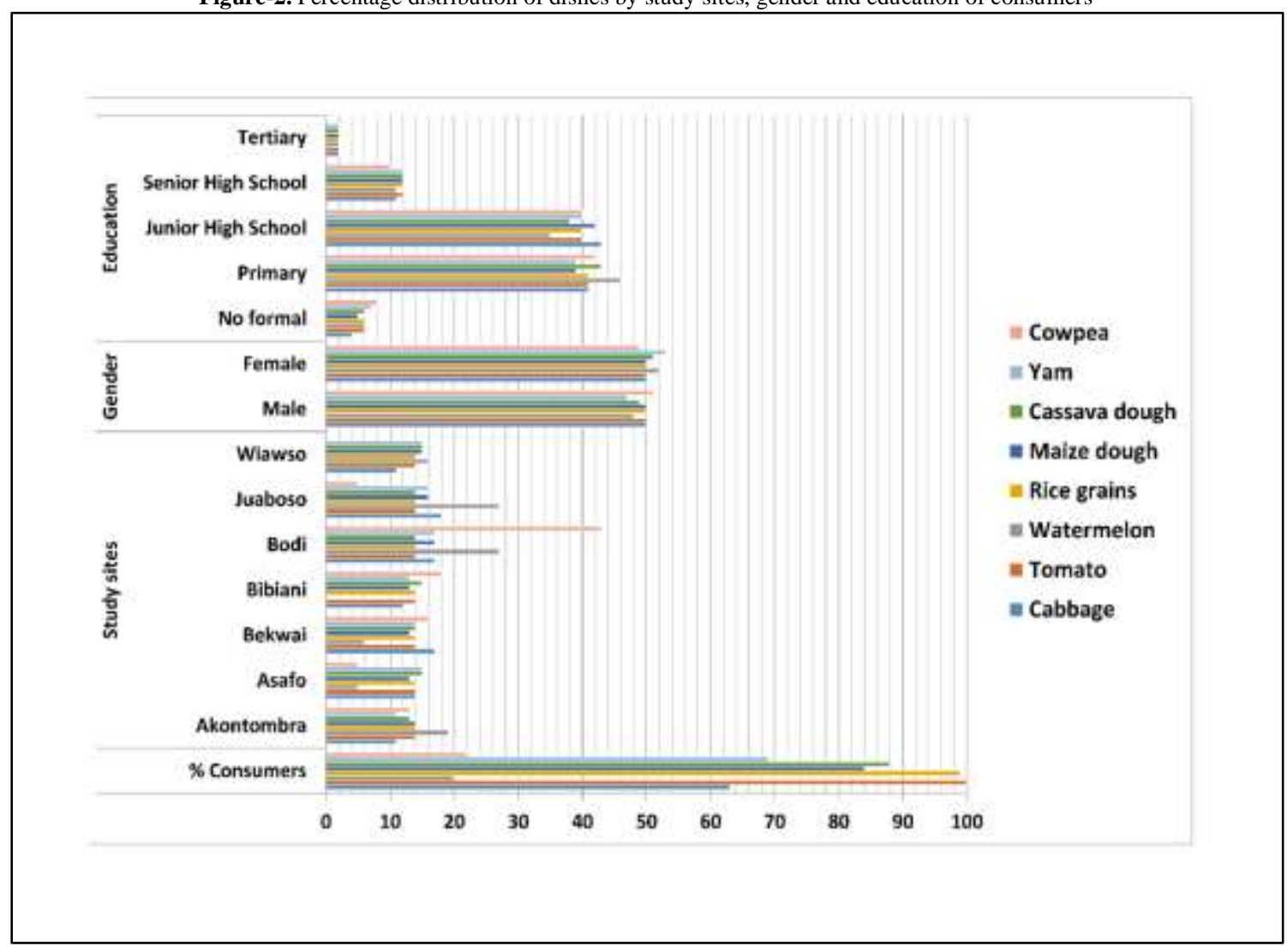

In a similar analysis, Burton-Freeman and Reimers [18] also found out that, tomato is the most consumed nonstarch vegetable in the US. This consumption pattern of tomatoes in the study is different in Brazil (16\%) [19]. The results also show that rice - based dishes (99\%) were consumed as the second highest unlike in Brazil [19], where rice is the most consumed (84\%). The least consumed crops were cowpea (22\%) and watermelon (20\%), similar to what has been reported in Brazil where fruits were least consumed (16\%) [19]. Studies have shown that the lycopene content and other bioactive components of tomatoes retard disease endpoints associated with hazards prevalent in mining areas $[18,20]$. Another factor that reinforces the high consumption of tomato compared to rice is that, in the study area almost every major meal is prepared with tomato as an ingredient (personal observation).

The results in Figure 2 show that more females consumed pineapple (55\%) and watermelon (52.4\%) relative to male consumers. This current study supports a major study across 23 countries, where it was found that differences in gender exists for food choices [21]. In their study, it was reported that women have greater tendency to patronize fruits and vegetables relative to men. Thus, their result is consistent with the findings of this current study. In addition, their study showed that this difference in fruit intake is explained by diet status and health beliefs. This assertion is corroborated by several other studies [22, 23]. Again, more females consumed carbohydrate-rich foods such as rice $(50.3 \%)$, maize $(50.4 \%)$, cassava $(51.1 \%)$ and yam $(52.6 \%)$ than the male population subgroup (Figure 2). This finding is contrary to a similar study by Tarnopolsky [24] where lower intake of carbohydrate was reported as accounting for the low glycogen levels. The results also showed that cabbage and tomato were equally consumed by male $(50 \%)$ and female $(50 \%)$ members of the population. This finding is contrary to the results from a study by Baker and Wardle [25], in which men were found to consume less vegetables than women. They further attributed this difference in vegetable consumption to ignorance of men about dietary recommendations for vegetables. Male consumers (50.7\%) ingested more cowpea than females. A similar study conducted in the US found that food intake and patronage show differences across gender [26].

The overwhelming majority ( $>90 \%$ ) of respondents had received at least primary education. According to the UNESCO [27] definition of literacy, members of the study area maybe described as literate. Consequently, the consumers are also likely to understand food safety public educational campaigns. This assertion is based on the finding by Wardle, et al. [28] that literacy correlates positively with appreciation of food safety and nutrition information. Consumers with primary (>39\%) and junior high school (JHS) (> 34\%) levels of education generally accounted for the bulk of consumption of the food crops.

\subsection{Processing Methods of Food Crops}

The study's results (Figure 3) show that in the study area consumers ingest cabbage in the stewed (29.5\%) form or salad form (slicing or chopping 70.6\%). Cabbage stew is described in Ashuntantang, et al. [29], in Cameroun. Tomato in the study area is stewed (77.6\%) for the most part as an accompaniment to grain and root tuber dishes. For example, Goldsmith, et al. [30] showed this to be the case in lunch served under the Ghana School Feeding program. Again, Steele-Dadzie, et al. [31] indicated that over 30\% of workers in Accra consume tomato stew. The current study shows that food service operators process tomato by boiling it as part of soup (22.4\%). Fernández- 
Ruiz, et al. [32] showed that tomato soup is similarly prepared in Spain. Principally, consumers ate cassava in the form cooked by boiling and pounding $(99.2 \%)$ into a local relish called "fufu". Flibert, et al. [33] outlined cooking methods of fufu in other African countries.

Figure-3. Processing methods

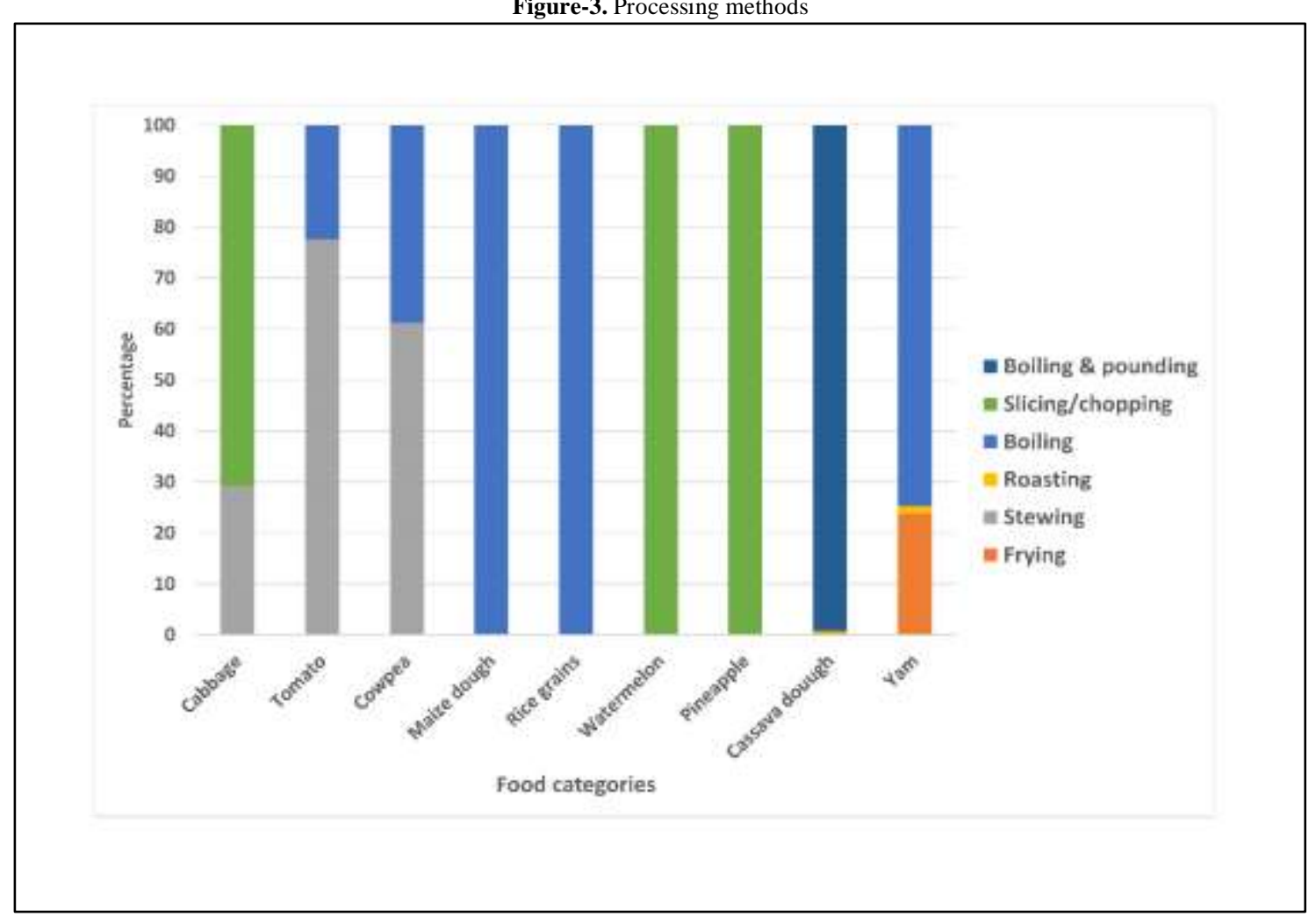

The study showed that when yam is consumed as "ampesi", it was chopped and boiled (74.7\%). Similarly, fried yam is a delicacy when the yam pieces are fried (23.9\%). The main processed forms of maize dough in the study area were banku, kenkey or porridge. Processors prepare them by boiling after milling maize grains and fermenting the dough. The processing is similar to what has been reported in other studies [31]. The current study also indicated that rice grains were prepared by boiling (plain rice) with tomato sauce ("jollof" rice) or with beans ("waakye"). Similarly, Uloma, et al. [34] found jollof as a continental dish in Nigerian hotels with a good patronage (22\%). Tugli, et al. [35] described waakye preparation methods, all of which involved boiling rice with beans. Watermelon and pineapple are consumed after chopping (100\%). According to EFSA, report of processing methods aids harmonization in food consumption comparisons $[3,5]$.

\subsection{Exposure Elements in the Consumption of Vegetables}

Consumers' body weight (Table 2) generally increased with age group; children (23.72 - $23.9 \mathrm{~kg}$ ), adolescents $(35.6-35.8 \mathrm{~kg})$ and adults $(56.6-56.7 \mathrm{~kg})$ at the mean level.

Table-2. Statistical distribution and metrics of exposure elements, vegetables

\begin{tabular}{|c|c|c|c|c|c|c|c|c|c|}
\hline & \multirow[t]{2}{*}{$\begin{array}{l}\text { Age } \\
\text { group }\end{array}$} & \multirow[b]{2}{*}{ Distribution } & \multirow[b]{2}{*}{ Min } & \multirow[b]{2}{*}{ Max } & \multicolumn{2}{|c|}{$\begin{array}{l}\text { Central } \\
\text { Tendencies }\end{array}$} & \multirow[b]{2}{*}{ Mode } & \multicolumn{2}{|c|}{ Percentiles } \\
\hline & & & & & Mean & Median & & 5 th & 95th \\
\hline \multirow[t]{14}{*}{ Cabbage } & $\begin{array}{l}3-9 \\
\text { years }\end{array}$ & & & & & & & & \\
\hline & BW & Triang $(11.390,31,31)$ & 14.0 & 31.0 & 23.9 & 22.0 & 21.0 & 14.8 & 31.0 \\
\hline & MF & ExtValue(56.931,32.005) & 15.84 & 190.03 & $75.74^{\mathrm{a}}$ & 79.18 & 31.67 & 19.00 & 183.69 \\
\hline & $\mathrm{EF}$ & Triang $(39.305,104,402.59)$ & 52 & 364 & 192 & 208 & 104 & 62 & 354 \\
\hline & ED & Uniform $(1,7)$ & 1 & 7 & 4 & 4 & 4 & 1.3 & 6.7 \\
\hline & \multicolumn{2}{|c|}{$10-17$ years } & & & & & & & \\
\hline & BW & ExtValue(32.4528,5.6311) & 22.0 & 55.0 & 35.6 & 35.0 & 30.0 & 27.0 & 49.0 \\
\hline & $\mathrm{MF}$ & $\begin{array}{l}\text { Weibull(1.4316,68.407,(12. } \\
920))\end{array}$ & 15.84 & 253.37 & $75.26^{\mathrm{a}}$ & 63.34 & 63.34 & 15.84 & 158.36 \\
\hline & $\mathrm{EF}$ & Uniform(52,364) & 52 & 364 & 194 & 208 & 208 & 52 & 364 \\
\hline & ED & Triang $(2,6,14)$ & 2 & 14 & 7.3 & 7.1 & 6 & 3.5 & 11.8 \\
\hline & \multicolumn{2}{|c|}{$18-64$ years } & & & & & & & \\
\hline & BW & Normal(56.6970,9.4673) & 32.0 & 78.0 & 56.7 & 56.0 & 54.0 & 42.0 & 73.7 \\
\hline & MF & $\begin{array}{l}\text { Triang }(15.840,15.840,229.2 \\
2)\end{array}$ & 15.84 & 221.70 & $77.98^{a}$ & 63.34 & 63.34 & 15.84 & 178.94 \\
\hline & $\mathrm{EF}$ & Uniform(52.00,364.00) & 52 & 364 & 181 & 156 & 156 & 52 & 364 \\
\hline
\end{tabular}


Academic Journal of Life Sciences

\begin{tabular}{|c|c|c|c|c|c|c|c|c|c|}
\hline & ED & Triang $(5,12,60)$ & 5 & 60 & 25 & 24 & 12 & 9.3 & 48.5 \\
\hline \multirow[t]{15}{*}{ Tomato } & $\begin{array}{l}3-9 \\
\text { years }\end{array}$ & & & & & & & & \\
\hline & BW & Triang $(11.524,31,31)$ & 14.0 & 31.0 & 23.7 & 22.5 & 18.0 & 16.9 & 31.0 \\
\hline & MF & ExtValue(94.067,44.268) & 19.61 & 274.60 & $118.98^{\mathrm{a}}$ & 137.30 & 137.30 & 56.88 & 209.38 \\
\hline & $\mathrm{EF}$ & Laplace $(364,19.3524)$ & 104 & 364 & 350 & 364 & 364 & 153 & 364 \\
\hline & ED & Triang $(1,6,9)$ & 1 & 9 & 5.3 & 5.4 & 6 & 2.4 & 7.9 \\
\hline & \multicolumn{2}{|c|}{$10-17$ years } & & & & & & & \\
\hline & BW & $\begin{array}{l}\text { InvGauss(36.236,1002.976, } \\
(20.023))\end{array}$ & 20.0 & 58.0 & 35.8 & 35.0 & 30.0 & 27.0 & 49.0 \\
\hline & MF & $\begin{array}{l}\text { LogLogistic(28.154,108.99, } \\
2.7030)\end{array}$ & 39.23 & 2059.50 & $168.38^{\mathrm{a}}$ & 137.30 & 137.30 & 68.65 & 343.25 \\
\hline & $\mathrm{EF}$ & Laplace $(364,10.5712)$ & 208 & 364 & 357 & 364 & 364 & 263 & 364 \\
\hline & ED & Triang $(9,14,16)$ & 9 & 16 & 13 & 13 & 14 & 10 & 15 \\
\hline & \multicolumn{2}{|c|}{$18-64$ years } & & & & & & & \\
\hline & BW & Logistic(56.6886,5.0163) & 32.0 & 78.0 & 56.6 & 57.0 & 58.0 & 41.6 & 73.0 \\
\hline & MF & $\begin{array}{l}\text { Pearson5(3.5474,490.94,(1 } \\
9.377))\end{array}$ & 19.61 & 617.85 & $171.09^{\mathrm{a}}$ & 137.30 & 137.30 & 68.65 & 442.79 \\
\hline & $\mathrm{EF}$ & Laplace $(364,18.7190)$ & 52 & 364 & 351 & 364 & 364 & 237 & 364 \\
\hline & ED & Triang $(19,55,63)$ & 19 & 63 & 46 & 47 & 55 & 28 & 59 \\
\hline
\end{tabular}

Values in the same column not sharing the same superscript are significantly different at $p<0.05$ in the Tukey's multiple comparison test.

Values with no superscript are not included in the test.

The modal weight for children $(18.0-21.0 \mathrm{~kg})$, adolescent $(30.0 \mathrm{~kg})$ and adult $(54.0-58.0 \mathrm{~kg})$ also followed similar trend. The mean vegetable consumption ranged from 75.74 to $118.98 \mathrm{~g} /$ day for children, 75.26 to 168.38 g/day for adolescents, and from 77.98 to $171.09 \mathrm{~g} /$ day for adults. This gender difference of consumption was however not significant $(\mathrm{p}>0.05)$. The modal consumption for children (31.67-137.30 g/day), adolescent (63.34$137.30 \mathrm{~g} /$ day) and adults (63.3-137.30 g/day) also followed an increasing trend. The $95^{\text {th }}$ percentile consumption estimate generally increased from children (183.69-209.38 g/day) through adolescents (158.36-346.25 g/day) to adults (178.94-442.79 g/day) (Table 2).

Among consumers in the study area, the modal exposure frequency among children (104-364 days/year) were slightly lower than among adolescents (208-364 days/year). The modal exposure frequency of adults (156-364 days/year) was slightly higher than the children group was, but it was lower than the adolescents' group was. Adult consumers have generally consumed vegetables for long as indicated by their exposure duration (5-19 years to 60-63 years). Their modal exposure duration (12-55 years) was higher than children (4-6 years) and adolescents (6-14 years). A high exposure frequency among adults (364 days/year) and adolescent (364 days/year) characterized the consumption of vegetables at the $95^{\text {th }}$ percentile level. The $95^{\text {th }}$ percentile exposure duration shows a trend from a low of children (6.7-7.9 years) to a high of adults (48.5-59.0 years) with adolescents in between (11.8-15.0 years).

At the $95^{\text {th }}$ percentile, the order (Table 2) of cabbage consumption in Italy [8] showed adults as the relatively high consumers $(100.00 \mathrm{~g} /$ day $)$ whereas, this current study's findings indicate children $(183.69 \mathrm{~g} /$ day $)$ as the he high consumers. Contrarily, whereas adolescents consumed at low level (158.36 g/day) in this current study, it was children in Italy (21.63 g/day) who consumed at a low level [8]. Generally, consumers in the current study consumed more cabbage $(158.36-183.69 \mathrm{~g} /$ day $)$ than consumers in Italy $(21.63-100.00 \mathrm{~g} / \mathrm{day}) \mathrm{did}$ at the $95^{\text {th }}$ percentile [8]. This trend also exists at the median estimate of consumption (Study 63.34-79.19 g/day > Italy 6.94$7.70 \mathrm{~g} /$ day) [8]. Similarly tomato consumption in Germany (adults $385.00>$ adolescents $270.88>$ children 48.80 $\mathrm{g} /$ day) was high among the adult population subgroup at the $95^{\text {th }}$ percentile [8]. This trend is similar to what was observed in this current study (Table 2), where consumers of tomato dishes were in the order: adults ( $442.79 \mathrm{~g} / \mathrm{day})$ $>$ adolescents (343.25 g/day) > children ( $209.38 \mathrm{~g} /$ day). The study reported identical levels of median consumption level of $137.30 \mathrm{~g} /$ day for all consumer subgroups. However, a study in German [8] puts adult (183.75 g/day) and adolescent (162.70 g/day) consumers of tomato soup as highest. This is in sharp contrast to what was observed in this current study for the adult and adolescent consumer groups. Again, children in the study area consumed more tomato dishes ( $137.30 \mathrm{~g} /$ day) compared to tomato soup consumers in Germany (49.90 g/day) at the median level [8]. It has been reported that inhabitants of the study area generally consumed vegetable dishes as accompaniments to carbohydrate dishes [36]. This may account for their high exposure frequency, high exposure duration as well as high consumption. In other words, since vegetable dishes and grain dishes are complementary products, the high consumption of vegetables is driven by the high consumption of grains. Furthermore, grain and root tuber dishes are cultivated in the study area as food security crops [37, 38]. Naturally, the high consumption of vegetables by the adult population subgroup compared to children and adolescents is attributable to their appreciation of the health advantages of vegetables including reducing the risks of several chronic diseases such cancers of the lung and cervix $[39,40]$. The findings of Serdul, et al. [41], corroborates the high vegetable consumption among adults, when they reported an observed high vegetable intake for adults compared to all other age groups in the US. Lares-Michel [42], assessed the effect of sociodemographics on tomato consumption in Mexico to reveal that income, employment and cooking culture correlates positively with tomato consumption. Still Baum and Weigelt [43] explain variation of tomato consumption levels in marketing terms. They contend that the format of retail explains the differences in tomato consumption. 


\subsection{Exposure Elements in the Consumption of Legumes}

The results show that mean body weight increases from children $(26.2 \mathrm{~kg})$ through adolescents $(36.4 \mathrm{~kg})$ to adults $(55.8 \mathrm{~kg})$. In addition, the modal weight for children $(26.0 \mathrm{~kg})$ and adolescents $(29.0 \mathrm{~kg})$ were lower than adults $(60.0 \mathrm{~kg})$ were. The modal consumption shows that adults (132.40 g/day) and children (132.40 g/day) consumed higher than adolescents $(44.13 \mathrm{~g} /$ day) did.

At the $95^{\text {th }}$ percentile, consumption increases from children (157.47 g/day) through adults (198.60 g/day) to adolescents as the high consumer group $(233.90 \mathrm{~g} /$ day $)$. The $95^{\text {th }}$ percentile exposure frequency shows that children (364 days/year) consumed legumes most frequently and adolescents (224 days/year) consumed at a lower exposure frequency. However, naturally, children had low exposure duration ( 5 years) at the $95^{\text {th }}$ percentile level followed by adolescents (10 years). Adults had high exposure duration (51 years) at the $95^{\text {th }}$ percentile. Adolescents consumed (Table 3) cowpea at a relatively high level $(233.90 \mathrm{~g} /$ day $)$, followed by adults (198.60 g/day) and children (154.47 $\mathrm{g} /$ day) at the $95^{\text {th }}$ percentile. Consumers in the United Kingdom (UK) on the other hand showed a different order of consumption: adults (116.38_g/day) > children (102.80 g/day) > adolescents ( $9.63 \mathrm{~g} /$ day) [8]. Overall, consumers in this current study recorded high cowpea consumption (154.47-233.90 g/day) compared to UK consumers (9.81$116.38 \mathrm{~g} /$ day) for population subgroups studied [8]. The median estimate of cowpea consumption (88.27-132.40 $\mathrm{g} /$ day) in the study was also higher relative to the corresponding consumer age groups in the UK (6.25-26.93 g/day) [8]. This trend can be explained by the fact that in the UK, consumers tend to spread their diets across a broad range of food categories whereas, compared to the current study area, where consumers tend to focus on few key staples as their source of food security $[44,45]$. Hence, consumers in the study are likely to consume large quantities of few crops compared to consumers in the UK. The adolescent population subgroup tends to be very physically active as their psychomotor skills is developing at a high rate [46]. Studies suggest that individuals engaged in physical activities tends to have high food consumption [46]. This may account for the adolescent population subgroup's high consumption of cowpeas in the study area. Further, this is particularly the case since in the study area, adolescents and children are usually engaged on household farms on weekends and after school hours or if they are out of school $[47,48]$. In addition, unschooled youth and school leavers may also be engaged in agriculture or informal mining since these are major occupations in the study area [49]. Their participation in such physically demanding engagements may account for their comparatively high consumption of cowpea.

Table-3. Statistical distribution and metrics of exposure elements, legumes

\begin{tabular}{|c|c|c|c|c|c|c|c|c|c|}
\hline & \multirow{2}{*}{$\begin{array}{l}\text { Age } \\
\text { group }\end{array}$} & \multirow[t]{2}{*}{ Distribution } & \multirow[b]{2}{*}{ Min } & \multirow[b]{2}{*}{ Max } & \multicolumn{3}{|c|}{ Central Tendencies } & \multicolumn{2}{|c|}{ Percentiles } \\
\hline & & & & & Mean & Median & Mode & 5 th & 95th \\
\hline \multirow[t]{15}{*}{$\begin{array}{l}\text { Cow } \\
\text { pea }\end{array}$} & $\begin{array}{l}3-9 \\
\text { years }\end{array}$ & & & & & & & & \\
\hline & BW & Uniform(19.00,31.00) & 19.0 & 31.0 & 26.2 & 26.0 & 26.0 & 19.0 & 31.0 \\
\hline & MF & Uniform $(52.00,154.47)$ & 22.07 & 154.47 & $93.17^{\mathrm{a}}$ & 132.40 & 132.40 & 22.07 & 154.47 \\
\hline & EF & Pareto(1.2796,52) & 52 & 364 & 139 & 156 & 156 & 52 & 364 \\
\hline & ED & Uniform $(1,5)$ & 1 & 5 & 3 & 3 & 3 & 1.3 & 5 \\
\hline & \multicolumn{2}{|c|}{$10-17$ years } & & & & & & & \\
\hline & BW & Triang $(27,27,54.624)$ & 27.0 & 52.0 & 36.4 & 35.0 & 29.0 & 27.0 & 49.9 \\
\hline & MF & Pareto(1.5107,44.130) & 44.13 & 264.80 & $100.30^{\mathrm{a}}$ & 88.27 & 44.13 & 44.13 & 233.90 \\
\hline & $\mathrm{EF}$ & Triang $(52,52,274.45)$ & 52 & 260 & 120 & 104 & 104 & 52 & 224 \\
\hline & ED & Triang $(1,6,12)$ & 12 & 12 & 6 & 6 & 6 & 3 & 10 \\
\hline & \multicolumn{2}{|c|}{$18-64$ years } & & & & & & & \\
\hline & $\mathrm{BW}$ & $\begin{array}{l}\text { Kumaraswamy(0.15737, } \\
0.27396,42.000,69.000)\end{array}$ & 42.0 & 69.0 & 55.8 & 58.0 & 60.0 & 42.3 & 67.5 \\
\hline & MF & Uniform $(22.07,198.60)$ & 22.07 & 198.60 & $97.09^{\mathrm{a}}$ & 88.27 & 132.40 & 22.07 & 198.60 \\
\hline & $\mathrm{EF}$ & Pareto(1.4983,52) & 52 & 364 & 121 & 104 & 52 & 52 & 348 \\
\hline & ED & Triang $(1,30,60)$ & 1 & 60 & 30 & 30 & 30 & 10 & 51 \\
\hline
\end{tabular}

Values in the same column not sharing the same superscript are significantly different at $\mathrm{p}<0.05$ in the Tukey's multiple comparison test. Values with no superscript are not included in the test.

\subsection{Exposure Elements in the Consumption of Roots and Tubers}

As expected, adults recorded (Table 4) the highest weight range $(73.0-74.0 \mathrm{~kg})$ followed by adolescents $(49.0$ $\mathrm{kg})$. Children recorded the lowest weight $(31.0 \mathrm{~kg})$. The modal body weight increases (Table 4) from children (18$28 \mathrm{~kg})>$ adolescents $(30 \mathrm{~kg})>$ adults $(54-58 \mathrm{~kg})$. Consumption trends from adults $(374.06-469.81 \mathrm{~g} /$ day $)$, high to children (374.06-822 $\mathrm{g} /$ day), low. However, at the $95^{\text {th }}$ percentile level of consumption (Table 4) adults constitute the highest consumer group (1272.40-1739.37 g/day) followed by adolescents (1096.22-1416.74 g/day) and children (91.10 - $578.57 \mathrm{~g} / \mathrm{gay})$. The modal exposure frequency among consumers in the study area show that children are the highest consumer group (104-364 days/year). Adults and adolescents consume at the same exposure frequency (52364 days/year). The $95^{\text {th }}$ percentile of exposure frequency presents a similar trend (Table 4) with children being the high group (286-364 days/year). Adults and adolescence follow (260-364 days/year) with the same exposure frequency. On the other hand, adults had the high exposure duration (54-59 years) with adolescents (15-16 years) and children (7-8 years) following at $95^{\text {th }}$ percentile level. The modal exposure duration (Table 4 ) in the study area also showed similar trend; adults (30-50 years) $>$ adolescents (13-16 years) > children (5-7 years). With respect to the 
$95^{\text {th }}$ percentile of cassava consumption (Table 4), the adolescent subgroup consumed at the high level (666.96 $\mathrm{g} /$ day), followed by children $(528.57 \mathrm{~g} /$ day) and adults at the low level (364.00 g/day). These levels of cassava consumption were higher than the corresponding age subgroups (adults $45.42 \mathrm{~g} /$ day $>$ adolescents $15.11 \mathrm{~g} / \mathrm{day}>$ children $5.04 \mathrm{~g} /$ day) in Portugal [8], where adults were the high consumer subgroup. This trend persists at the Portuguese median level of consumption estimate (adults $5.21 \mathrm{~g} /$ day > adolescents $5.11 \mathrm{~g} /$ day $>$ children $3.51 \mathrm{~g}$ day). This study's finding, however, differ in that adolescents were the high consumer subgroup (adolescents 267.86 $\mathrm{g} /$ day > children $160.71 \mathrm{~g} /$ day > adults $104.00 \mathrm{~g} /$ day) at the median. Adults were rather the low consumer subgroup. The results (Table 4) also show that cassava consumption level among adults (364.00 g/day), adolescent (666.96 $\mathrm{g} /$ day) and children (578.57 g/day) exceeded corresponding age subgroups in Portugal (adults $42.42 \mathrm{~g} /$ day, adolescent $15.11 \mathrm{~g} /$ day and children $5.13 \mathrm{~g} / \mathrm{day}$ ) [8]. Cassava is the single most important food crop cultivated in the study area in terms of cultivated acreage and annual production. It had the highest acreage (74.43 Hectares) and production (735.80 MT) among crops grown in the study area [50]. This may explain the high consumption of cassava.

The high consumption of cassava by adolescents maybe explained by their preference for dishes with high starch content (19.02-30.99\%) [51]. Portugal and other countries, with a trend of consuming less cereals and root starches may be undergoing what [52] refers to as the "substitution effect" towards the consumption of more sugar, animal and vegetable fats [53].

Table-4. Statistical distribution and metrics of exposure elements, root tubers

\begin{tabular}{|c|c|c|c|c|c|c|c|c|c|}
\hline & \multirow[t]{2}{*}{ Age group } & \multirow[t]{2}{*}{ Distribution } & \multirow[b]{2}{*}{ Min } & \multirow[b]{2}{*}{ Max } & \multicolumn{3}{|c|}{ Central Tendencies } & \multicolumn{2}{|c|}{ Percentiles } \\
\hline & & & & & Mean & Median & Mode & $5^{\text {th }}$ & $95^{\text {th }}$ \\
\hline \multirow[t]{15}{*}{ Maize } & $3-9$ years & & & & & & & & \\
\hline & $\mathrm{BW}$ & $\begin{array}{l}\text { Triang }(12.069,31,3 \\
\text { 1) }\end{array}$ & 14.0 & 31.0 & 24.8 & 26.0 & 28.0 & 15.5 & 31.0 \\
\hline & MF & $\begin{array}{l}\text { Triang }(59.477,187 . \\
03,1405.6)\end{array}$ & 93.51 & $1309.20^{\mathrm{a}}$ & 503.04 & 374.06 & 374.06 & 140.27 & 1215.69 \\
\hline & $\mathrm{EF}$ & $\begin{array}{l}\text { Expon }(73.517,(49 . \\
465))\end{array}$ & 52 & 364 & 126 & 104 & 104 & 52 & 286 \\
\hline & ED & Uniform $(1,8)$ & 1 & 8 & 5 & 5 & 5 & 2 & 8 \\
\hline & \multicolumn{2}{|l|}{$10-17$ years } & & & & & & & \\
\hline & $\mathrm{BW}$ & $\begin{array}{l}\text { InvGauss(32.456,6 } \\
97.368,(3.5220))\end{array}$ & 20.0 & 58.0 & 36.0 & 35.0 & 30.0 & 27.0 & 49.2 \\
\hline & MF & $\begin{array}{l}\text { Expon }(375.43,(184 \\
.27))\end{array}$ & 187.03 & $1963.80^{\mathrm{a}}$ & 562.46 & 374.06 & 374.06 & 187.03 & 1416.74 \\
\hline & $\mathrm{EF}$ & $\begin{array}{l}\text { Expon }(68.059,(51 . \\
500))\end{array}$ & 52 & 364 & 120 & 104 & 52 & 52 & 260 \\
\hline & ED & Triang $(1,13,16)$ & 1 & 16 & 10 & 10 & 13 & 4 & 15 \\
\hline & \multicolumn{2}{|l|}{ 18-64 years } & & & & & & & \\
\hline & $\mathrm{BW}$ & $\begin{array}{l}\text { Normal(56.2043,8. } \\
5562)\end{array}$ & 32 & 74 & 56 & 57 & 54 & 42 & 71 \\
\hline & MF & $\begin{array}{l}\text { Triang(187.03,187. } \\
03,2093.0)\end{array}$ & 187.03 & $1963.80^{b}$ & 756.16 & 654.60 & 374.06 & 187.03 & 1739.37 \\
\hline & $\mathrm{EF}$ & $\begin{array}{l}\text { Expon }(82.194,(51 . \\
116))\end{array}$ & 52 & 364 & 134 & 104 & 52 & 52 & 260 \\
\hline & ED & Uniform $(1,62)$ & 1 & 62 & 31 & 32 & 30 & 4 & 59 \\
\hline \multirow{11}{*}{$\begin{array}{l}\text { Rice } \\
\text { grains }\end{array}$} & $3-9$ years & & & & & & & & \\
\hline & $\mathrm{BW}$ & $\begin{array}{l}\text { Triang }(11.524,31,3 \\
1)\end{array}$ & 14.0 & 31.0 & 23.7 & 22.5 & 18.0 & 16.9 & 31.0 \\
\hline & MF & $\begin{array}{l}\text { Laplace(548.11,22 } \\
4.384,(156.6,1174 . \\
52))\end{array}$ & 156.60 & 1174.52 & $574.90^{\mathrm{a}}$ & 548.11 & 548.11 & 230.99 & 1100.14 \\
\hline & $\mathrm{EF}$ & $\begin{array}{l}\text { Triang(79.826,364, } \\
364)\end{array}$ & 104 & 364 & 300 & 364 & 364 & 104 & 364 \\
\hline & ED & Triang $(1,7,8)$ & 1 & 8 & 5 & 6 & 7 & 2 & 7 \\
\hline & \multicolumn{2}{|l|}{ 10-17 years } & & & & & & & \\
\hline & $\mathrm{BW}$ & $\begin{array}{l}\text { InvGauss(37.533,1 } \\
113.742,(20.322))\end{array}$ & 20 & 58 & 36 & 35 & 30 & 27 & 49 \\
\hline & MF & $\begin{array}{l}\text { Gamma(25.053,51. } \\
901,(117.620))\end{array}$ & 117.45 & 1370.27 & $641.68^{\mathrm{a}}$ & 587.26 & 822.17 & 156.60 & 1096.22 \\
\hline & $\mathrm{EF}$ & $\begin{array}{l}\text { Triang }(28.323,364, \\
364)\end{array}$ & 52 & 364 & 286 & 312 & 364 & 104 & 364 \\
\hline & ED & Triang $(1,16,16)$ & 1 & 16 & 11 & 11 & 16 & 4 & 16 \\
\hline & \multicolumn{2}{|l|}{ 18-64 years } & & & & & & & \\
\hline
\end{tabular}


Academic Journal of Life Sciences

\begin{tabular}{l|l|l|l|l|l|l|l|l|l}
\hline & BW & $\begin{array}{l}\text { Logistic(56.564,4.9 } \\
514,(32))\end{array}$ & 32.0 & 78.0 & 56.4 & 57.0 & 58.0 & 41.5 & 72.0 \\
\cline { 2 - 10 } & MF & $\begin{array}{l}\text { Weibull(1.8637,68 } \\
7.61,(23.361))\end{array}$ & 78.30 & 1761.78 & $635.03^{\mathrm{a}}$ & 587.26 & 469.81 & 137.03 & 1272.40 \\
\cline { 2 - 10 } & EF & $\begin{array}{l}\text { Uniform(52.00,364 } \\
.00)\end{array}$ & 52 & 364 & 232.8073 & 208 & 364 & 52 & 364 \\
\cline { 2 - 11 } & ED & Triang(1,50,63) & 1 & 63 & 38 & 40 & 50 & 13 & 57 \\
\hline
\end{tabular}

Values in the same column not sharing the same superscript are significantly different at $p<0.05$ in the Tukey's multiple comparison test.

Values with no superscript are not included in the test.

Yam consumption (Table 4) ranged from a low of $91.10 \mathrm{~g} /$ day (children) to a high of $136.65 \mathrm{~g} /$ day (adults) with $121.46 \mathrm{~g} /$ day (adolescents) in between. This trend is different for consumers of yam in the UK [8], where the children age category were the highest $(60.27 \mathrm{~g} /$ day), with adolescents being the low consuming population subgroup (6.45 g/day). In the UK, adults consumed at an intermediate level $(45.93 \mathrm{~g} /$ day $)$ between children $(60.27$ $\mathrm{g} /$ day) and adolescents $(6.45 \mathrm{~g} /$ day). Among the age subgroups, adolescents in the study area preferred cassava (666.96 g/day) to yam ( $121.46 \mathrm{~g} /$ day) because it is probably less costly [53, 54]. According to Farris, et al. [55], the price of food is essential to consumption choices, thus, adults with higher incomes can afford more yam dishes compared to adolescents or children. At the median level generally, (30.37-60.73 g/day) consumers of yam in the study consumed greater quantities of yam compared to consumers in the UK (6.45-22.50 g/day) [8]. This finding is associated with the fact that yam is a tropical crop [56] consumed essentially by minority demographic subgroups such as migrants in the UK [57].

The modal weight (Table 5) of consumers of cereal grains were from 18 to $28 \mathrm{~kg}$ (children), $30 \mathrm{~kg}$ (adolescent) and 54-58 kg (adults). The modal consumption ranges from 374.06-548.11 g/day (children), 374.06-822.17 g/day (adolescents) and 374.06-869.81 g/day (adults). The $95^{\text {th }}$ percentile of consumption (Table 5) ranges increases from children (1100.14-1215.69 g/day) through adolescents (1096.22-1416.74g/day) to adults (1272.40-1739.37 g/day). The modal exposure duration ranges for children (104-364 days/year) adolescents (104-364 days/year) and adults (104-364 days/year) were the same. On the contrary, children consumed high (286-364 days/year) compared to adolescents (260-364 days /year) and adults (260-364 days/ year) at the $95^{\text {th }}$ percentile level. The modal exposure (Table 5) duration among grain consumers increased from children (5-7 years) followed by, adolescents (13-16 years) and adults (30-50 years). As expected, at the $95^{\text {th }}$ percentile estimate of exposure duration, adults consumed grains for the longest period (57-59 years) followed by adolescents (15-16 years) and children (7-8 years).

Table-5. Statistical distribution and metrics of exposure elements, cereal grains

\begin{tabular}{|c|c|c|c|c|c|c|c|c|c|}
\hline & \multirow[t]{2}{*}{ Age group } & \multirow[t]{2}{*}{ Distribution } & \multirow[b]{2}{*}{ Min } & \multirow[b]{2}{*}{ Max } & \multicolumn{3}{|c|}{ Central Tendencies } & \multicolumn{2}{|c|}{ Percentiles } \\
\hline & & & & & Mean & Median & Mode & $5^{\text {th }}$ & $95^{\text {th }}$ \\
\hline \multirow[t]{15}{*}{ Pineapple } & 3-9 years & & & & & & & & \\
\hline & BW & $\begin{array}{l}\text { Triang }(15.677,3 \\
1,31)\end{array}$ & 18.0 & 31.0 & 26.7 & 29.0 & 30.0 & 18.0 & 31.0 \\
\hline & MF & $\begin{array}{l}\text { Uniform(15.41, } \\
61.66)\end{array}$ & 15.41 & 61.66 & $37.18^{\mathrm{a}}$ & 30.83 & 30.83 & 15.41 & 61.66 \\
\hline & $\overline{E F}$ & $\begin{array}{l}\text { Uniform(52.00, } \\
104.00)\end{array}$ & 52 & 104 & 80 & 104 & 104 & 52 & 104 \\
\hline & ED & Triang $(2,5,6)$ & 2 & 6 & 4 & 4 & 5 & 3 & 6 \\
\hline & \multicolumn{2}{|l|}{$10-17$ years } & & & & & & & \\
\hline & BW & $\begin{array}{l}\text { Triang(24.552,3 } \\
0,53.047)\end{array}$ & 25.0 & 51.0 & 36.0 & 36.0 & 30.0 & 28.8 & 47.3 \\
\hline & MF & $\begin{array}{l}\text { Expon(29.232,( } \\
15.030))\end{array}$ & 15.41 & 246.63 & $44.24^{\mathrm{a}}$ & 30.83 & 30.83 & 15.41 & 95.57 \\
\hline & $\mathrm{EF}$ & $\begin{array}{l}\text { Pareto(3.0777,5 } \\
\text { 2) }\end{array}$ & 52 & 208 & 80 & 52 & 52 & 52 & 156 \\
\hline & ED & Triang $(3,7,9)$ & 3 & 9 & 6 & 6 & 7 & 4 & 8 \\
\hline & \multicolumn{2}{|l|}{ 18-64 years } & & & & & & & \\
\hline & BW & $\begin{array}{l}\text { Normal(58.327 } \\
3,8.2216)\end{array}$ & 42.0 & 78.0 & 58.3 & 59.0 & 59.0 & 42.8 & 72.4 \\
\hline & MF & $\begin{array}{l}\text { Expon(37.841,( } \\
14.722))\end{array}$ & 15.41 & 184.97 & $52.13^{\mathrm{a}}$ & 30.83 & 30.83 & 15.41 & 184.97 \\
\hline & $\overline{E F}$ & $\begin{array}{l}\text { Pareto( }(2.5319,5 \\
\text { 2) }\end{array}$ & 52 & 312 & 86 & 52 & 52 & 52 & 166 \\
\hline & ED & Triang $(8,50,56)$ & 8 & 56 & 38 & 40 & 50 & 18 & 52 \\
\hline \multirow{3}{*}{$\begin{array}{l}\text { Watermel } \\
\text { on }\end{array}$} & 3-9 years & & & & & & & & \\
\hline & $\mathrm{BW}$ & $\begin{array}{l}\text { Uniform(18.00, } \\
31.00)\end{array}$ & 18.0 & 31.0 & 26.1 & 30.0 & 30.0 & 18.0 & 31.0 \\
\hline & $\mathrm{MF}$ & $\begin{array}{l}\text { Pareto(1.1623,3 } \\
2.660)\end{array}$ & 32.66 & 195.99 & $94.36^{\mathrm{a}}$ & 65.33 & 65.33 & 32.66 & 195.99 \\
\hline
\end{tabular}


Academic Journal of Life Sciences

\begin{tabular}{|c|c|c|c|c|c|c|c|c|}
\hline $\mathrm{EF}$ & $\begin{array}{l}\text { Pareto(2.5115,5 } \\
\text { 2) }\end{array}$ & 52 & 156 & 87 & 52 & 52 & 52 & 156 \\
\hline ED & Uniform(2,5) & 2 & 5 & 4 & 4 & 4 & 2 & 5 \\
\hline \multicolumn{2}{|c|}{ 10-17 years } & & & & & & & \\
\hline$\overline{B W}$ & $\begin{array}{l}\text { Normal(36.965 } \\
5,5.6662)\end{array}$ & 25.0 & 50.0 & 37.0 & 38.0 & 40.0 & 27.0 & 49.5 \\
\hline MF & $\begin{array}{l}\text { Pareto(1.4462,3 } \\
2.660)\end{array}$ & 32.66 & 293.98 & $79.97^{\mathrm{a}}$ & 65.33 & 32.66 & 32.66 & 244.98 \\
\hline $\mathrm{EF}$ & $\begin{array}{l}\text { Pareto(3.7456,5 } \\
\text { 2) }\end{array}$ & 52 & 156 & 74 & 52 & 52 & 52 & 156 \\
\hline ED & Triang $(4,6,17)$ & 4 & 17 & 9 & 9 & 6 & 5 & 14 \\
\hline \multicolumn{2}{|c|}{ 18-64 years } & & & & & & & \\
\hline BW & $\begin{array}{l}\text { Laplace }(59,8.711 \\
6)\end{array}$ & 32.0 & 74.0 & 58.8 & 59.0 & 59.0 & 32.6 & 73.7 \\
\hline MF & $\begin{array}{l}\text { Pareto(1.1726,32. } \\
660)\end{array}$ & 32.66 & 881.94 & $109.75^{\mathrm{a}}$ & 65.33 & 65.33 & 32.66 & 656.55 \\
\hline $\mathrm{EF}$ & Pareto $(3.4074,52)$ & 52 & 156 & 75 & 52 & 52 & 52 & 140 \\
\hline ED & Triang $(10,20,65)$ & 10 & 65 & 32 & 30 & 20 & 15 & 54 \\
\hline
\end{tabular}

Values in the same column not sharing the same superscript are significantly different at $\mathrm{p}<0.05$ in the Tukey's multiple comparison test. Values with no superscript are not included in the test.

Consumption of maize (Table 5) increases from children ( $1215.69 \mathrm{~g} /$ day) through adolescents $(1416.74 \mathrm{~g} /$ day $)$ to adults $(1739.37 \mathrm{~g} / \mathrm{day})$ at the $95^{\text {th }}$ percentile. Consumption of maize (Table 5) increases from children $(1215.69$ $\mathrm{g} /$ day) through adolescents $(141.74 \mathrm{~g} /$ day $)$ to adults $\left(1739.37 \mathrm{~g} /\right.$ day) at the $95^{\text {th }}$ percentile. Similarly, EFSA [8] reported maize grain consumption pattern : adults $9.19 \mathrm{~g} /$ day > children $8.37 \mathrm{~g} /$ day $>$ adolescent $7.69 \mathrm{~g} / \mathrm{day}$, in which adults were the high consumer group at the $95^{\text {th }}$ percentile.

The $95^{\text {th }}$ percentile maize grain consumption was greater in the study area $(1215.69-1739.37 \mathrm{~g} /$ day) than in Denmark (7.69 - 9.19 g/day). This disparity is reflected at the median level of maize consumption for adults (Study $654.60>$ Denmark $1.94 \mathrm{~g} /$ day) adolescents (Study $374.06>$ Denmark $1.80 \mathrm{~g} /$ day) and children ( Study $374.06>$ Denmark $1.80 \mathrm{~g} /$ day) as well EFSA [8].

Indeed, the combined consumption of both maize flour and maize grains in Denmark were much less than maize consumption in the study area. Culturally, members of the study area prepare maize dishes for the household usually on a daily basis [58-60]. These maize dishes were not commercially processed and this fact may account for the observed differences in consumption levels between Denmark and the study area. Adult consumers may prefer maize dishes relative to both children and adolescents because maize dishes or products are generally filling and can be used to prepare a variety of dishes suitable for breakfast, lunch and supper [61].

Rice grains consumption (Table 5) increased from adolescents (1096.22 g/day) to adults (1272.40 g/day) with children at $1100.14 \mathrm{~g} /$ day. Corresponding level of estimate in France [8] also show adults as the high consumer subgroup for rice pudding (259.00 g/day) and rice grain (300.00 g/day). However, whereas adolescents $(1096.22$ $\mathrm{g} /$ day) were the low consumer group in the study area, children (125.00 g/day) were the low consumer group in France [8]. Among French consumers, adolescents' rice pudding consumption (207.50 g/day) was in between those of adults and children. Additionally, in France, both adults and adolescents consumed the same amount of polished rice grain (300 g/day) and they both constitute the high population subgroup [8]. Thus, consumers of the study area ate more rice than those in France. The relatively low rice consumption of children maybe due to their poor preference for rice varieties on the market [62]. The high consumption of rice in this study area for all age groups compared to consumers in France may be attributed to the high rice import that makes rice generally available at affordable prices all year round $[63,64]$.

From the results in Table 6, we see that the modal body weight of consumers ranges from children $(30 \mathrm{~kg})$ and adolescents $(30-40 \mathrm{~kg}$ ) to adults $(59 \mathrm{~kg})$ in the study area. The modal consumption level of pineapple and watermelon of adolescents (30.83-32.66g/day) low compared to levels of both children and adults (30.83$65.33 \mathrm{~g} /$ day) age categories in the study area. The $95^{\text {th }}$ percentile level of consumption estimates indicates that adults are the high consumers (184.97-656.55g/day) with children consuming at relatively low level (61.66-195.99g/day). The modal exposure frequency for children (52-104 days/years) was high relative to adolescents (52 days/year) and adults (52 days/year). The $95^{\text {th }}$ percentile of exposure frequency however shows that adults consume at 140-166 days/year followed by adolescent (156 days/year) and children (104-156 days/year).

Table-6. Statistical distribution and metrics of exposure elements, fruits

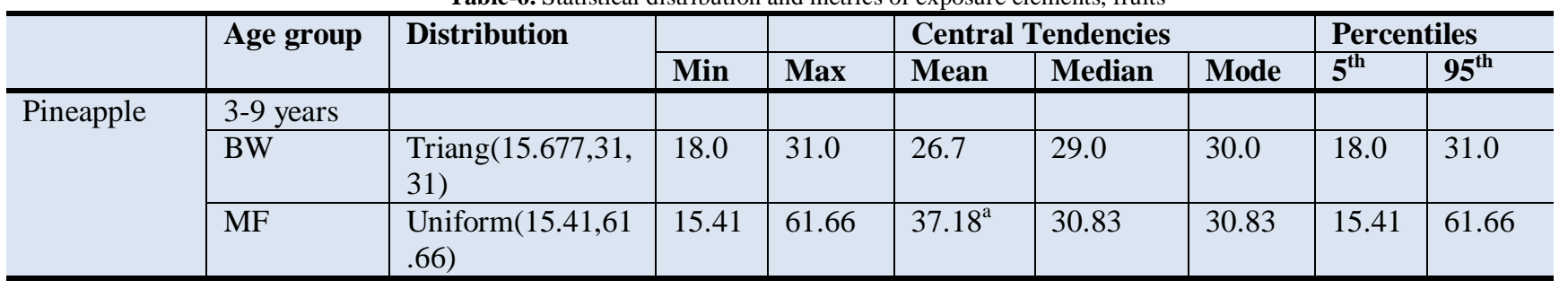


Academic Journal of Life Sciences

\begin{tabular}{|c|c|c|c|c|c|c|c|c|c|}
\hline & $\mathrm{EF}$ & $\begin{array}{l}\text { Uniform }(52.00,10 \\
4.00)\end{array}$ & 52 & 104 & 80 & 104 & 104 & 52 & 104 \\
\hline & ED & Triang $(2,5,6)$ & 2 & 6 & 4 & 4 & 5 & 3 & 6 \\
\hline & $10-1$ & & & & & & & & \\
\hline & BW & $\begin{array}{l}\text { Triang }(24.552,30, \\
53.047)\end{array}$ & 25.0 & 51.0 & 36.0 & 36.0 & 30.0 & 28.8 & 47.3 \\
\hline & MF & $\begin{array}{l}\text { Expon(29.232,(15 } \\
.030))\end{array}$ & 15.41 & 246.63 & $44.24^{\mathrm{a}}$ & 30.83 & 30.83 & 15.41 & 95.57 \\
\hline & $\mathrm{EF}$ & Pareto(3.0777,52) & 52 & 208 & 80 & 52 & 52 & 52 & 156 \\
\hline & ED & Triang $(3,7,9)$ & 3 & 9 & 6 & 6 & 7 & 4 & 8 \\
\hline & $18-6$ & & & & & & & & \\
\hline & BW & $\begin{array}{l}\text { Normal(58.3273,8 } \\
.2216)\end{array}$ & 42.0 & 78.0 & 58.3 & 59.0 & 59.0 & 42.8 & 72.4 \\
\hline & $\mathrm{MF}$ & $\begin{array}{l}\text { Expon(37.841,(14 } \\
.722))\end{array}$ & 15.41 & 184.97 & $52.13^{\mathrm{a}}$ & 30.83 & 30.83 & 15.41 & 184.97 \\
\hline & $\mathrm{EF}$ & Pareto(2.5319,52) & 52 & 312 & 86 & 52 & 52 & 52 & 166 \\
\hline & ED & Triang $(8,50,56)$ & 8 & 56 & 38 & 40 & 50 & 18 & 52 \\
\hline Watermelon & $3-9 y$ & & & & & & & & \\
\hline & BW & $\begin{array}{l}\text { Uniform }(18.00,31 \\
.00)\end{array}$ & 18.0 & 31.0 & 26.1 & 30.0 & 30.0 & 18.0 & 31.0 \\
\hline & MF & $\begin{array}{l}\text { Pareto(1.1623,32. } \\
660)\end{array}$ & 32.66 & 195.99 & $94.36^{\mathrm{a}}$ & 65.33 & 65.33 & 32.66 & 195.99 \\
\hline & $\mathrm{EF}$ & Pareto(2.5115,52) & 52 & 156 & 87 & 52 & 52 & 52 & 156 \\
\hline & ED & Uniform $(2,5)$ & 2 & 5 & 4 & 4 & 4 & 2 & 5 \\
\hline & $10-1$ & & & & & & & & \\
\hline & BW & $\begin{array}{l}\text { Normal(36.9655,5 } \\
.6662)\end{array}$ & 25.0 & 50.0 & 37.0 & 38.0 & 40.0 & 27.0 & 49.5 \\
\hline & MF & $\begin{array}{l}\text { Pareto(1.4462,32. } \\
660)\end{array}$ & 32.66 & 293.98 & $79.97^{\mathrm{a}}$ & 65.33 & 32.66 & 32.66 & 244.98 \\
\hline & $\mathrm{EF}$ & Pareto(3.7456,52) & 52 & 156 & 74 & 52 & 52 & 52 & 156 \\
\hline & ED & Triang $(4,6,17)$ & 4 & 17 & 9 & 9 & 6 & 5 & 14 \\
\hline & $18-6$ & & & & & & & & \\
\hline & BW & $\begin{array}{l}\text { Laplace }(59,8.711 \\
6)\end{array}$ & 32.0 & 74.0 & 58.8 & 59.0 & 59.0 & 32.6 & 73.7 \\
\hline & MF & $\begin{array}{l}\text { Pareto(1.1726,32. } \\
660)\end{array}$ & 32.66 & 881.94 & $109.75^{\mathrm{a}}$ & 65.33 & 65.33 & 32.66 & 656.55 \\
\hline & $\mathrm{EF}$ & Pareto(3.4074,52) & 52 & 156 & 75 & 52 & 52 & 52 & 140 \\
\hline & ED & Triang $(10,20,65)$ & 10 & 65 & 32 & 30 & 20 & 15 & 54 \\
\hline
\end{tabular}

Values in the same column not sharing the same superscript are significantly different at $p<0.05$ in the Tukey's multiple comparison test. Values with no superscript are not included in the test.

As expected, the modal exposure duration for children (4-5 years), adolescents (6-7 years) and adults (20-50 years) increases in that order. Pineapple consumption increased in the order with age: children $(61.66 \mathrm{~g} / \mathrm{day})<$ adolescents $(95.57 \mathrm{~g} /$ day $)<$ adults $(184.97 \mathrm{~g} /$ day $)$ at the $95^{\text {th }}$ percentile. In Sweden [8], this trend is similarly followed as: children $(51.25 \mathrm{~g} /$ day $)<$ adolescents $(55.00 \mathrm{~g} /$ day $)<$ adults $(65.14 \mathrm{~g} /$ day $)$. The median estimate of pineapple consumption was the same for all population subgroups in the study area ( $30.83 \mathrm{~g} / \mathrm{day})$. Among Swedish consumers [8] however, adults consumed lower ( $11.86 \mathrm{~g} / \mathrm{day})$ than adolescents consumed ( $27.50 \mathrm{~g} / \mathrm{day})$. Children consumed (12.50 g/day) in between the levels of adults and adolescents. The findings of Nti, et al. [65] suggest that adults' high consumption of pineapple may be associated with their better appreciation of balanced nutrition and nutritional value of pineapple. High production of pineapple occasioned by amenable soil and climatic conditions in the study area may explain the high consumption in the study area compared to consumption in Sweden [66, 67]. Bianchi and Mortimer [57], indicate that another factor that may have contributed to the high pineapple consumption in the study is ethnocentrism associated with food choice, attitudes supportive of local food production or patronizing local food. At the $95^{\text {th }}$ percentile, watermelon consumption among children (195.99 g/day) were low compared to its consumption among adolescents ( $244.98 \mathrm{~g} /$ day) and adults $(656.55 \mathrm{~g} /$ day) .

In the National Dietary Survey in Estonia [8, 68], however, adolescents registered lower consumption $(242.58$ g/day) relative to adults (942.90 g/day) and children(506.25 g/day). Furthermore, at the $95^{\text {th }}$ percentile (Study 195.99 - $656.55 \mathrm{~g} /$ day > Estonia 242.58 - $942.90 \mathrm{~g} /$ day) and median (Study $65.33 \mathrm{~g} /$ day > Estonia 66.00 - 175.00 $\mathrm{g} /$ day) $[8,68]$, levels watermelon consumption was greater in Estonia than the study area for all population subgroups. According to Khan, et al. [69] and Vivek, et al. [70], due to the perishability and seasonality of fruits and vegetables including watermelon and pineapple, their exposure frequency is rather comparatively low: 140-156 days/year $\left(95^{\text {th }}\right.$ percentile). There appears to be standards in Estonia to keep watermelon fresh and safe for long [71, 72]. This may contribute to the high consumption there compared to consumption in the study area. 


\title{
4. Conclusion
}

Food consumer characteristics and consumption analytics have become essential in monitoring the impacts of food-borne hazards in mining areas. Age specific food consumption data enables the profiling of vulnerable groups for targeting and prompt intervention. The findings show that consumption data: exposure frequency, exposure duration and mass of food consumed, show variability across population age subgroups. Adolescents maybe comparatively more vulnerable to contaminants in cowpea and cassava, whereas adults maybe vulnerable to contaminants in yam, maize, rice, pineapple, and watermelon based on both high mass of food consumed and exposure duration. However, children may have more vulnerability to contaminants in cowpeas, root tubers, rice and maize grains on the basis of high exposure frequency. Overall, rice and maize grain consumption have high consumption levels, exposure duration and exposure frequency. The study therefore calls for baselining the exposures and risks to food contaminants in the study area for the vulnerable age groups using updated food consumption data.

\section{Declarations of Interest}

\author{
None
}

\section{Acknowledgement}

We are thankful to the staff of the Municipal Health Directorate and the Municipal Hospital, Sefwi Wiaso, of special mention Mr William Gyan and Mr Kenneth Kwame Kye-Amoah for support in data collection.

\section{References}

[1] WHO, 2002. "Diet, nutrition and the prevention of chronic diseases, Report of a Joint WHO/FAO Expert Consultation. Technical Report Series 916," Geneva."

[2] WHO and FAO, 2003. Diet, nutrition and the prevention of chronic diseases. WHO Tech. Rep. Ser., pp. 1160.

[3] EFSA, 2011. "Use of the EFSA Comprehensive European Food Consumption Database in Exposure Assessment." EFSAJ., vol. 9, p. 2097.

[4] JECFA, 2011. Safety evaluation of certain contaminants in food. Geneva: FAO/WHO.

[5] EFSA, 2014. "Guidance on the EU Menu methodology." EFSA J., vol. 12, pp. 1-77.

[6] US EPA, 2001. Process for conducting probabilistic risk assessment. Washington, DC: Volume III-Part A.

[7] Fotopoulos, S. B., 2002. "Applied probability models." The American Statistician, vol. 56, pp. 248-248. Available: https://doi.org/10.1198/tas.2002.s2

[8] EFSA, 2018. The EFSA comprehensive european food consumption database. Data Collection and Analysis.

[9] Fosu-Mensah, B. Y., 2018. "Assessment of heavy metal contamination and distribution in surface soils and plants along the west coast of Ghana." West African J. Appl. Ecol., vol. 26, pp. 167-178.

[10] Hadzi, G. Y., Ayoko, G. A., Essumang, D. K., and Osae, S. K. D., 2019. "Contamination impact and human health risk assessment of heavy metals in surface soils from selected major mining areas in Ghana." Environmental Geochemistry and Health. Springer, vol. 41, pp. 2821-2843.

[11] Food and Agriculture Organisation, 2017. "Data, FAOSTAT." Available: http://www.fao.org/faostat/en/\#data

[12] Moy, G. G. and Vannoort, R. W., 2013. Total diet studies. 1st ed. New York: Springer.

[13] Boafo, J., 2013. The impact of deforestation on forest livelihoods in Ghana. Africa Portal Online Libr., p. 49.

[14] Mensah, I., Boakye-Danquah, J., Suleiman, N., Nutakor, S., and Suleiman, M. D., 2020. "Small-scale Mining, the SDGs and Human Insecurity in Ghana." In Africa and the Sustainable Development Goals, Springer. pp. 81-90.

[15] Ministry of Food and Agriculture, 2011. "Agriculture in Ghana Facts and figures."

[16] Ministry of Food and Agriculture Republic of Ghana, 2017. "Western Region." Available: http://mofa.gov.gh/site/?page_id=660

[17] US EPA, 1989. Risk assessment guidance for superfund (Rags): Part a. Risk Assessment.

[18] Burton-Freeman and Reimers, K., 2011. "Tomato consumption and health: Emerging benefits." Am. J. Lifestyle Med., vol. 5, pp. 182-191.

[19] de Souza, M. A., Pereira, R. A., Yokoo, E. M., Levy, R. B., and Sichieri, R., 2013. "Most consumed foods in Brazil: National dietary survey 2008-2009." Rev. Saude Publica, vol. 47, pp. 190-199.

[20] Canene-Adams, K., Campbell, J. K., Zaripheh, S., Jeffery, E. H., and Erdman Jr, J. W., 2005. "The tomato as a functional food." J. Nutr., vol. 135, pp. 1226-1230.

[21] Wardle, J., Haase, A. M., Steptoe, A., Nillapun, M., Jonwutiwes, K., and Bellisle, F., 2004. "Gender differences in food choice: The contribution of health beliefs and dieting." Ann. Behav. Med., vol. 27, pp. 107-116.

[22] Deliens, T., Verhoeven, H., De Bourdeaudhuij, I., Huybrechts, I., Mullie, P., Clarys, P., and Deforche, B., 2018. "Factors associated with fruit and vegetable and total fat intake in university students: A crosssectional explanatory study." Nutrition and dietetics: the journal of the Dietitians Association of Australia, vol. 75, pp. 151-158. Available: https://doi.org/10.1111/1747-0080.12399 
[23] Emanuel, A. S., McCully, S. N., Gallagher, K. M., and Updegraff, J. A., 2012. "Theory of Planned Behavior explains gender difference in fruit and vegetable consumption." Appetite, vol. 59, pp. 693-697.

[24] Tarnopolsky, M. A., 2001. "Gender differences in carbohydrate loading are related to energy intake." $J$. Appl. Physiol., vol. 91, pp. 225-30.

[25] Baker, A. H. and Wardle, J., 2003. "Sex differences in fruit and vegetable intake in older adults." Appetite, vol. 40, pp. 269-275.

[26] Glanz, K., Basil, M., Maibach, E., Goldberg, J., and Snyder, D. A. N., 1998. "Why americans eat what they do: Taste, nutrition, cost, convenience and weight control concerns as influences on food consumption." $J$. Am. Diet. Assoc., vol. 98, pp. 1118-1126.

[27] UNESCO, 2005. "Literacy for life: Education for all global monitoring report 2006."

[28] Wardle, J., Parmenter, K., and Waller, J., 2000. "Nutrition knowledge and food intake." Appetite, vol. 34, pp. 269-275.

[29] Ashuntantang, G. E., Fouda, H., Kaze, F. F., Halle, M.-P., Tabi-Arrey, C., and Biwole-Sida, M., 2016. "A practical approach to low protein diets for patients with chronic kidney disease in Cameroon." BMC Nephrol, vol. 17, p. 126.

[30] Goldsmith, P., Andrade, J., Cornelius, M., Asigbee, M., Atim, P., and Tamimie, C., 2019. "National school lunch nutrition and cost profile: A case study of the ghana school feeding programme." Food Nutr. Bull., vol. 40, pp. 41-55.

[31] Steele-Dadzie, R. K., Larvie, D. Y., Amoako-Mensah, A., Asante, M., and Intiful, F. D., 2017. "Comparison of lunch consumed by corporate workers and artisans in a metropolitan area in Accra, Ghana." Niger. J. Nutr. Sci., vol. 38, pp. 50-60.

[32] Fernández-Ruiz, V., Domínguez, L., Sánchez-Mata, M. C., Gervás, C., and Cámara, M., 2016. "Factors affecting consumer acceptance towards Spanish tomato products: a preliminary study on gazpacho soup." XIV International Symposium on Processing Tomato 1159, vol. 1159, pp. 223-230.

[33] Flibert, G., Abel, T., and Aly, S., 2016. "African cassava traditional fermented food: The microorganism's contribution to their nutritional and safety values-a review." Int. J. Curr. Microbiol. Appl. Sci., vol. 5, pp. 664-687.

[34] Uloma, A., Okoro, O., and Chinenye, M., 2019. "Evaluation of Indigenous Cuisine in Hotels and Restaurants in Aba, Abia State, Nigeria." Archives of Current Research International, vol. 16, pp. 1-7. Available: https://doi.org/10.9734/acri/2019/v16i330094

[35] Tugli, L. S., Essuman, E. K., Kortei, N. K., Nsor-Atindana, J., Nartey, E. B., and Ofori-Amoah, J., 2019. "Bioactive constituents of waakye; a local Ghanaian dish prepared with Sorghum bicolor (L.) Moench leaf sheaths." Sci. African, vol. 3, p. e00049.

[36] Armar-Klemesu, M., 2000. Urban agriculture and food security, nutrition and health. Grow. Cities, Grow. Food. Urban Agric. Policy Agenda, pp. 99-118.

[37] Montagnac, J. A., Davis, C. R., and Tanumihardjo, S. A., 2009. "Nutritional value of cassava for use as a staple food and recent advances for improvement." Compr. Rev. Food Sci. Food Saf., vol. 8, pp. 181-194.

[38] Nweke, F., Spencer, D. S. C., and Lynam, J. K., 2002. The cassava transformation: Africas bestkept secret. Michigan State University Press, p. 273.

[39] Boeing, H., 2012. "Critical review: Vegetables and fruit in the prevention of chronic diseases." Eur. J. Nutr., vol. 51, pp. 637-663.

[40] Ziegler, R. G., 1991. "Vegetables, fruits, and carotenoids and the risk of cancer." Am. J. Clin. Nutr., vol. 53, pp. 251S-259S.

[41] Serdul, M. K., Gillespie, C., Kettel-Khan, L., Farris, R., Seymour, J., and Denny, C., 2004. "Trends in fruit and vegetable consumption among adults in the United States: Behavioral risk factor surveillance system, 1994-2000." Am. J. Public Health, vol. 94, pp. 1014-1018.

[42] Lares-Michel, M., 2018. "The relationship between consumption, socioeconomic level and reasons of tomato intake in Mexico." Agric. Sci., vol. 9, p. 777.

[43] Baum, C. M. and Weigelt, R., 2019. "How where i shop influences what i buy: The importance of the retail format in sustainable tomato consumption." In Demand, Complexity, and Long-Run Economic Evolution, Springer. pp. 141-169.

[44] Chauvin, N. D., Mulangu, F., and Porto, G., 2012. Food production and consumption trends in subSaharan Africa: Prospects for the transformation of the agricultural sector. Africa New York, NY, USA: UNDP Reg. Bur.

[45] Kc, K. B., Legwegoh, A. F., Therien, A., Fraser, E. D. G., and Antwi-Agyei, P., 2018. "Food price, food security and dietary diversity: A comparative study of Urban Cameroon and Ghana." J. Int. Dev., vol. 30, pp. 42-60.

[46] Drenowatz, C., 2017. "Cross-sectional and longitudinal associations between different exercise types and food cravings in free-living healthy young adults." Appetite, vol. 118, pp. 82-89.

[47] Raphael, D., Dontoh, S., Adjei, A., and Badu, F. K., 2019. "Factors that account for low enrollment in community-based senior high schools in the ashanti region of Ghana." Int. J. Sci. Res. Manag., vol. 7, pp. 877-919.

[48] Asare-Konadu, C., 2018. There is no child labour in Ghana: an empirical study of how parents and children experience child labour in Ghana. Nord Universitet. 
[49] Hoedoafia, M. A., Cheabu, B. S. N., and Korang, V., 2014. "The effects of small scale gold mining on living conditions: A case study of the west gonja district of Ghana." Int. J. Soc. Sci. Res., vol. 2, pp. 151164.

[50] Government of Ghana, 2017. Western region. Government of Ghana.

[51] Moorthy, S. N. and Padmaja, G., 2002. "Starch content of cassava tubers." J. Root Crop., vol. 28, pp. 3037.

[52] Kearney, J., 2010. "Food consumption trends and drivers." Philosophical Transactions of the Royal Society B: Biological Sciences, vol. 3651, pp. 2793-2807.

[53] Pingali, P., 2007. "Westernization of Asian diets and the transformation of food systems: Implications for research and policy." Food Policy, vol. 32, pp. 281-298.

[54] Laizer, J. S., Baharanyi, N. R., Tackie, D. N. O., Zabawa, R., and Kadigi, R. M. J., 2018. "Determinants of consumer preference for and expenditure on rice in the Kilimanjaro Region, Tanzania." Prof. Agric. Work. J., vol. 6, p. 26.

[55] Farris, A. R., Misyak, S., O’Keefe, K., VanSicklin, L., and Porton, I., 2019. "Understanding the drivers of food choice and barriers to diet diversity in Madagascar." J. Hunger Environ. Nutr., vol. 15, pp. 1-13.

[56] Saranraj, P., Behera, S. S., and Ray, R. C., 2019. "Traditional foods from tropical root and tuber crops: Innovations and challenges." In Innovations in Traditional Foods, Elsevier. pp. 159-191.

[57] Bianchi, C. and Mortimer, G., 2015. "Drivers of local food consumption: a comparative study." Br. Food J., vol. 117, pp. 2282-2299.

[58] Kruger, R., Schönfeldt, H. C., and Owen, J. H., 2008. "Food-coping strategy index applied to a community of farm-worker households in South Africa." Food Nutr. Bull., vol. 29, pp. 3-14.

[59] Nti, C. A., 2008. "Household dietary practices and family nutritional status in rural Ghana." Nutr. Res. Pract., vol. 2, pp. 35-40.

[60] Oldewage-Theron, W. H., Dicks, E. G., and Napier, C. E., 2006. "Poverty, household food insecurity and nutrition: coping strategies in an informal settlement in the Vaal Triangle, South Africa." Public Health, vol. 120 , pp. $795-804$.

[61] Serna-Saldivar, S. O. and Carrillo, E. P., 2019. "Food uses of whole corn and dry-milled fractions." In Corn, Elsevier. pp. 435-467.

[62] Mottaleb, K. A. and Mishra, A. K., 2016. "Rice consumption and grain-type preference by household: A Bangladesh case." J. Agric. Appl. Econ., vol. 48, pp. 298-319.

[63] Amanor-Boadu, V., 2012. "Rice price trends in Ghana (2006-2011), Monitoring, Evaluation and Technical Support Services (METSS)-Ghana Research and Issue Paper Series. No. 02-2012-June 2012. Kansas." Available: https://www.agmanager.info/sites/default/files/RiceTrends 02-2012_Vincent.pdf

[64] Andam, K. S., Ragasa, C., Asante, S., and Amewu, S., 2019. Can local products compete against imports in West Africa? Supply-and demand-side perspectives on chicken, rice, and tilapia in Accra, Ghana, No 1821. IFPRI discussion papers, International Food Policy Research Institute (IFPRI).

[65] Nti, C. A., Hagan, J., Bagina, F., and Seglah, M., 2011. "Knowledge of nutrition and health benefits and frequency of consumption of fruits and vegetables among Ghanaian homemakers." African J. Food Sci., vol. 5, pp. 333-339.

[66] Hossain, M. F., Akhtar, S., and Anwar, M., 2015. "Nutritional value and medicinal benefits of pineapple." Int. J. Nutr. Food Sci., vol. 4, pp. 84-88.

[67] Lobo, M. G. and Paull, R. E., 2017. Handbook of pineapple technology: production, postharvest science, processing and nutrition. John Wiley and Sons.

[68] National Institute for Health Development (Estonia), Nurk, E., Nelis, K., Saamel, M., Martverk, M., and Nelis, L., 2017. "National Dietary Survey among 11-74 years old individuals in Estonia." EFSA Supporting Publication, vol. 14, p. 22.

[69] Khan, K. A., Goyal, M. R., and Kalne, A. A., 2019. Processing offruits and vegetables: From farm to fork. CRC Press.

[70] Vivek, K., Singh, S. S., and P, R. C., 2019. "A review on postharvest management and advances in the minimal processing of fresh-cut fruits and vegetables." J. Microbiol. Biotechnol. Food Sci., vol. 2019, pp. 1178-1187.

[71] Banson, K. E., Sun, D., and Banson, I. B., 2016. "Systemic view of the market opportunities for fresh cuts convenience in Ghana." Int. J. Mark. Bus. Syst., vol. 2, pp. 141-156.

[72] Santo, D., Graça, A., Nunes, C., and Quintas, C., 2016. "Survival and growth of Cronobacter sakazakii on fresh-cut fruit and the effect of UV-C illumination and electrolyzed water in the reduction of its population." Int. J. Food Microbiol., vol. 231, pp. 10-15. 